\title{
Analisis Perbandingan Kinerja Keuangan Perbankan Syariah Bank Umum Syariah (BUS) dengan Unit Usaha Syariah (UUS) pada Bank Umum Konvensional
}

Wiwin Kurniasari

Email: wiwinkurniasari@yahoo.com

IAIN Salatiga

\begin{abstract}
This study aims to analyze the comparative financial performance of Islamic Banking with Conventional Banking (Shariah Business Unit) for each financial ratio and overall. The measurements of banking performance was used in this study are CAMELS ratios (Capital, Asset, Management, Earnings, Liquidity, and Sensitivity to Market Risk). This study uses 11 Shariah Banks and 12 Shariah Business Unit in 2012.
\end{abstract}

This study shows that there are no differences between Shariah Banks and Shariah Business Unit in Capital Adequacy Ratio and Ratio Quality of Earning Asset, but there are differences in Management Ratio, Profitability Ratio, Liquidity Ratio, and Sensitivity Ratio in each and overall.

Keyword: financial performance,capital adequacy ratio, Islamic banking, return on asset, loan to deposit ratio.

\begin{abstract}
Abstrak
Penelitian ini bertujuan untuk menganalisa perbandingan kinerja keuangan perbankan syariah yaitu Bank Umum Syariah (BUS) dengan Bank Konvensional dari Unit Usaha Syariah (UUS) untuk masing-masing rasio keuangan dan secara keseluruhan. Ukuran kinerja bank yang digunakan dalam penelitian ini adalah rasio keuangan bank CAMELS (Capital, Asset, Management, Earnings, Liquidity, sensitivity to market risk), yang meliputi Capital Adequacy Ratio (mewakili rasio permodalan), pembentukan penyisihan penghapusan aktiva produktif (mewakili rasio kualitas aktiva produktif), Net Profit Margin/NPM(mewakili rasio manajemen), Return on
\end{abstract}


Assets (ROA), Loan to Deposit Ratio (mewakili rasio likuiditas) dan Interest Rate Risk Ratio (mewakili rasio Sensitivitas terhadap Risiko Pasar).Teknik pengambilan sampel yang digunakan dalam penelitian ini adalah purposive sampling yang merupakan teknik pengambilan sampel dengan pertimbangan atau kriteria tertentu. Sampel yang dipergunakan peneliti adalah11 Bank Umum Syariah (BUS) dan 12 Unit Usaha Syariah (UUS) yang memiliki kelengkapan laporan keuangan tahun 2012 yang berupa neraca, laporan laba rugi, komitmen dan kontinjensi, kualitas aktiva produktif dan informasi lainnya, perhitungan kewajiban penyediaan modal minimum (KPMM). Berdasarkan hasil penelitian, analisis uji beda rata-rata $t$-Test memperlihatkan tidak ada perbedaan yang signifikan antara kinerja keuangan perbankan syariah pada Bank Umum Syariah (BUS) dengan perbankan konvensional yang mempunyai Unit Usaha Syariah (UUS) jika dilihat dari rasio permodalan (CAR) dan rasio kualitas aktiva produktif (PPAP). Ada perbedaan yang signifikan antara kinerja keuangan perbankan syariah (Bank Umum Syariah) dengan perbankan konvensional yang mempunyai Unit Usaha Syariah (UUS) jika dilihat dari rasio manajemen (NPM), rasio profitabilitas (ROA), rasio likuiditas (LDR), dan rasio sensitifitas terhadap reaksi pasar-Interest Rate Risk Ratio (IRRR), serta jika dilakukan analisis secara keseluruhan kinerja keuangan perbankan syariah.

Kata kunci: kinerja keuangan, rasio permodalan, perbankan syariah, rasio likuiditas

\section{Pendahuluan}

Keberadaan bank syariah di tengah-tengah perbankan konvensional adalah untuk menawarkan sistem perbankan alternatif bagi masyarakat yang membutuhkan layanan jasa perbankan tanpa harus khawatir atas persoalan bunga (riba). Bank syariah didirikan dengan tujuan untuk mempromosikan dan mengembangkan penerapan prinsip-prinsip Islam dan tradisinya ke dalam transaksi keuangan dan perbankan serta bisnis yang terkait. Prinsip utama yang diikuti oleh bank syariah adalah: 1) Larangan riba (bunga) dalam berbagai bentuk tradisi, 2) Melakukan kegiatan usaha dan perdagangan berdasarkan perolehan pendapatan dan keuntungan yang sah (revenue sharing atau profit sharing), 3) Memberikan zakat sebagai salah satu instrumen dalam perhitungan pembagian keuntungan dan laporan keuangan (Arifin, 2002: 3). 
Pemberlakuan UU No. 10 tahun 1998 tentang perubahan UU No. 7 tahun 1992 tentang perbankan telah memberi kesempatan luas untuk pengembangan jaringan perbankan Syariah. Selanjutnya pemberlakuan UU No. 23 tahun 1999 tentang Bank Indonesia, menegaskan bahwa BI mempersiapkan perangkat peraturan dan fasilitas penunjang yang mendukung operasional bank syariah. Kedua undang-undang tersebut menjadi dasar hukum penerapan dual banking system di Indonesia. Dual Banking system yang dimaksud adalah terselenggaranya dua sistem perbankan (non syariah dan syariah) secara berdampingan, yang pelaksanaannya diatur dalam berbagai peraturan perundang-undangan yang berlaku.

Sebagai salah satu lembaga keuangan, bank perlu menjaga kinerjanya agar dapat beroperasi secara optimal. Terlebih lagi bank syariah harus bersaing dengan bank konvensional yang dominan dan telah berkembang pesat di Indonesia. Persaingan yang semakin tajam ini harus disertai dengan manajemen yang baik untuk bisa bertahan di industri perbankan. Salah satu faktor yang harus diperhatikan oleh bank untuk bisa terus bartahan hidup adalah kinerja (kondisi keuangan) bank. Oleh karena itu, penulis tertarik untuk melakukan penelitian dengan judul "Analisis Perbandingan Kinerja Keuangan Perbankan Pada Bank Umum Syariah (BUS) dengan Unit Usaha Syariah (UUS)".

Berdasarkan uraian latar belakang masalah tersebut, maka yang menjadi permasalahan dalam penelitian ini adalah:

1. Bagaimana kinerja keuangan perbankan pada bank umum syariah (BUS) jika dibandingkan dengan unit usaha syariah (UUS) untuk masing-masing rasio keuangan?

2. Adakah perbedaan yang signifikan atas kinerja keuangan perbankan pada bank umum syariah (BUS) jika dibandingkan dengan unit usaha syariah (UUS) secara keseluruhan?

Batasan masalah dalam penelitian ini adalah sebagai berikut:

1. Bank yang dipilih dalam penelitian ini adalah bank syariah yang telah terdiri dari bank umum syariah (BUS) dan unit usaha syariah (UUS) bukan pada bank umum konvensional. 
2. Informasi yang digunakan untuk mengukur kinerja bank adalah berdasar Laporan Publikasi Keuangan Bank Indonesia periode 2012.

3. Ukuran kinerja bank yang digunakan dalam penelitian ini adalah rasio keuangan bank, yang meliputi Capital Adequacy Ratio (mewakili rasio permodalan), pembentukan Penyisihan Penghapusan Aktiva Produktif (mewakili rasio kualitas aktiva produktif), Net Profit Margin/NPM (mewakili rasio manajemen), Return on Assets (ROA), Loan to Deposit Ratio (mewakili rasio likuiditas) dan Interest Rate Risk Ratio (mewakili rasio Sensitivitas terhadap Risiko Pasar).

\section{Tinjauan Pustaka}

Menurut Pedoman Standar Akuntansi Keuangan (PSAK) No 1, tujuan laporan keuangan adalah menyediakan informasi yang menyangkut posisi keuangan, kinerja serta perubahan posisi keuangan suatu perusahaan dalam pengambilan keputusan. Laporan yang disajikan oleh suatu perusahaan dalam hal ini lembaga perbankan pada periode tertentu bertujuan, antara lain: (1) Memberikan informasi tentang posisi keuangan bank menyangkut harta bank, kewajiban bank serta modal bank pada periode tertentu; (2) Memberikan informasi menyangkut laba rugi suatu bank pada periode tertentu; (3) Memberikan informasi bagi pihak-pihak yang berkepentingan dengan laporan keuangan yang disajikan suatu bank; (4) Memberikan informasi tentang performance suatu bank.

\section{Prinsip Dasar Perbankan Syariah}

Allah telah menghalalkan jual beli dalam setiap kegiatan ekonomi dan melarang keras praktek riba dan jual beli terlarang lainnya yang di jelaskan dalam al-Quran yang artinya:

"Orang-orang yang makan (mengambil) riba tidak dapat berdiri melainkan seperti berdirinya orang yang kemasukan syaitan lantaran (tekanan) penyakit gila. Keadaan mereka yang demikian itu, adalah disebabkan mereka berkata (berpendapat), sesungguhnya jual beli itu sama dengan riba, padahal Allah telah menghalalkan jual beli dan 
mengharamkan riba. Orang-orang yang telah sampai kepadanya larangan dari Tuhannya, lalu terus berhenti (dari mengambil riba), maka baginya apa yang telah diambilnya dahulu (sebelum datang larangan); dan urusannya (terserah) kepada Allah. Orang yang kembali (mengambil riba), maka orang itu adalah penghuni-penghuni neraka; mereka kekal di dalamnya”. (Q.S. Al-Baqarah : 275).

Batasan-batasan bank syariah yang harus menjalankan kegiatannya berdasar pada syariat Islam, menyebabkan bank syariah harus menerapkan prinsip-prinsip yang sejalan dan tidak bertentangan dengan syariat Islam. Adapun prinsip-prinsip bank syariah adalah sebagai berikut:

a. Prinsip Titipan atau Simpanan (al-Wadi'ah)

Al-Wadiah dapat diartikan sebagai titipan murni dari satu pihak ke pihak lain, baik individu maupun badan hukum, yang harus dijaga dan dikembalikan kapan saja si penitip menghendaki.

b. Prinsip Bagi Hasil (Profit Sharing)

Sistem ini adalah suatu sistem yang meliputi tatacara pembagian hasil usaha antara penyedia dana dengan pengelola dana. Bentuk produk yang berdasarkan prinsip ini adalah:

(1) Al-Mudharabah

Al-Mudharabah adalah akad kerjasama usaha antara dua pihak di mana pihak pertama (shahibul maal) menyediakan seluruh (100\%) modal, sedangkan pihak lainnya menjadi pengelola (mudharib). Keuntungan usaha secara mudharabah dibagi menurut kesepakatan yang dituangkan dalam kontrak, sedangkan apabila rugi ditanggung oleh pemilik modal selama kerugian itu bukan akibat kelalaian si pengelola. Seandainya kerugian ini diakibatkan karena kecurangan atau kelalaian si pengelola, si pengelola harus bertanggung jawab atas kerugian tersebut. Akad mudharabah secara umum terbagi menjadi dua jenis:

\section{(a). Mudharabah Muthlaqah}

Adalah bentuk kerjasama antara shahibul maal dan mudharib yang cakupannya sangat luas dan tidak dibatasi oleh spesifikasi jenis usaha, waktu, dan daerah bisnis. 
(b).Mudharabah Muqayyadah

Adalah bentuk kerjasama antara shahibul maal dan mudharib di mana mudharib memberikan batasan kepada shahibul maal mengenai tempat, cara, dan obyek investasi.

(2) Al-Musyarakah

Al-musyarakah adalah akad kerjasama antara dua pihak atau lebih untuk suatu usaha tertentu di mana masing-masing pihak memberikan kontribusi dana dengan kesepakatan bahwa keuntungan dan risiko akan ditanggung bersama sesuai dengan kesepakatan. Al-Qur'an menjelaskan tentang musyarakah dalam ayat yang artinya sebagai berikut:

Ketahuilah, sesungguhnya apa saja yang dapat kamu peroleh sebagai rampasan perang, maka sesungguhnya seperlima untuk Allah, Rasul, kerabat Rasul, anak-anak yatim, orang-orang miskin dan ibnussabil (Q.S. Al-Anfaal : 41).

c. Prinsip Jual Beli (Al-Tijarah)

Prinsip ini merupakan suatu sistem yang menerapkan tata cara jual beli, di mana bank akan membeli terlebih dahulu barang yang dibutuhkan atau mengangkat nasabah sebagai agen bank melakukan pembelian barang atas nama bank, kemudian bank menjual barang tersebut kepada nasabah dengan harga sejumlah harga beli ditambah keuntungan (margin). Implikasinya berupa:

(1) Al-Murabahah

Murabahah adalah akad jual beli barang dengan menyatakan harga perolehan dan keuntungan (margin) yang disepakati oleh penjual dan pembeli.

(2) Salam

Salam adalah akad jual beli barang pesanan dengan penangguhan pengiriman oleh penjual dan pelunasannya dilakukan segera oleh pembeli sebelum barang pesanan tersebut diterima sesuai syaratsyarat tertentu. 


\section{(3) Istishna'}

Istishna' adalah akad jual beli antara pembeli dan produsen yang juga bertindak sebagai penjual. Cara pembayarannya dapat berupa pembayaran dimuka, cicilan, atau ditangguhkan sampai jangka waktu tertentu. Barang pesanan harus diketahui karakteristiknya secara umum yang meliputi: jenis, spesifikasi teknis, kualitas, dan kuantitasnya.

Bank dapat bertindak sebagai pembeli atau penjual. Jika bank bertindak sebagai penjual kemudian memesan kepada pihak lain untuk menyediakan barang pesanan dengan cara istishna maka hal ini disebut istishna paralel.

\section{d. Prinsip Sewa (Al-Ijarah)}

Al-Ijarah adalah akad pemindahan hak guna atas barang atau jasa, melalui pembayaran upah sewa, tanpa diikuti dengan pemindahan hak kepemilikan atas barang itu sendiri. Al-ijarah terbagi kepada dua jenis: (1) Ijarah, sewa murni, (2) Ijarah al muntahiya bit tamlik merupakan penggabungan sewa dan beli, di mana si penyewa mempunyai hak untuk memiliki barang pada akhir masa sewa.

e. Prinsip Jasa (Fee-Based Service)

Prinsip ini meliputi seluruh layanan non-pembiayaan yang diberikan bank. Bentuk produk yang berdasarkan prinsip ini antara lain:

(1) Al-Wakalah

Nasabah memberi kuasa kepada bank untuk mewakili dirinya melakukan pekerjaan jasa tertentu, seperti transfer.

(2) Al-Kafalah

Jaminan yang diberikan oleh penanggung kepada pihak ketiga untuk memenuhi kewajiban pihak kedua atau yang ditanggung.

\section{(3) Al-Hawalah}

Adalah pengalihan utang dari orang yang berutang kepada orang lain yang wajib menanggungnya. Kontrak hawalah dalam perbankan biasanya diterapkan pada Factoring (anjak piutang), Post-dated check, di mana bank bertindak sebagai juru tagih tanpa membayarkan dulu piutang tersebut. 
(3) Al-Rahn

Adalah menahan salah satu harta milik si peminjam sebagai jaminan atas pinjaman yang diterimanya. Barang yang ditahan tersebut memiliki nilai ekonomis. Dengan demikian, pihak yang menahan memperoleh jaminan untuk dapat mengambil kembali seluruh atau sebagian piutangnya. Secara sederhana dapat dijelaskan bahwa rahn adalah semacam jaminan utang atau gadai.

(5) Al-Qardh

Al-Qardh adalah pemberian harta kepada orang lain yang dapat ditagih atau diminta kembali atau dengan kata lain meminjamkan tanpa mengharapkan imbalan. Produk ini digunakan untuk membantu usaha kecil dan keperluan sosial. Dana ini diperoleh dari dana zakat, infaq dan shadaqah.

\section{Kinerja Perbankan Syariah}

Berkaitan dengan pengukuran kinerja perbankan di Indonesia, Bank Indonesia (BI) sebagai regulator perbankan di Indonesia selain memberikan dukungannya dalam pertumbuhan perbankan syariah di Indonesia juga telah memberikan peraturan dalam bentuk pengawasan (penilaian) terhadap perbankan syariah. Pengawasan tersebut berhubungan dengan sistem penilaian yaitu dengan dikeluarkannya Peraturan Bank Indonesia Nomor: 9/1/PBI/2007 tentang Sistem Penilaian Tingkat Kesehatan Bank Umum Berdasarkan Prinsip Syariah yang menjelaskan bahwa penilaian tingkat kesehatan bank mencakup penilaian terhadap faktor-faktor capital (permodalan), asset quality (kualitas asset), management (manajemen), earning (rentabilitas), liquidity (likuiditas), dan sensitivity to market risk (sensivitas terhadap risiko pasar) atau lebih dikenal sebagai CAMELS.

Masyarakat perlu memahami ukuran kinerja perbankan untuk mencapai tujuan investasinya. CAMELS (Capital, Asset, Management, Earnings, Liquidity, sensitivity to market risk) adalah salah satu indikator kualitas kesehatan perbankan yang dapat memproyeksikan kondisi keuangan bank di masa yang akan datang. Bank dengan peringkat CAMELS di atas 81 adalah bank dengan pendapatan yang kuat dan aktiva tak lancar yang 
sedikit. Bank dengan peringkat CAMELS di bawah 81, oleh pengawas bank dipandang lemah dalam pendapatan atau permodalan. Nilai CAMELS digunakan oleh pengawas bank untuk mengetahui bank yang memerlukan pengawasan ketat meskipun demikian peringkat CAMELS tidak pernah dinformasikan secara luas (Humas BI, 2010).

\section{Tinjauan Empiris}

Brock dan Rojaz Suarez (2000) meneliti pengaruh $C A R$, BOPO, NPL dan $L D R$ terhadap laba pada perusahaan perbankan di Amerika Latin menunjukkan $C A R$ berpengaruh signifikan positif terhadap laba pada bankbank di Bolivia dan Columbia sedangkan di Argentina, Chilli dan Peru tidak mempunyai pengaruh yang signifikan terhadap laba, BOPO berpengaruh signifikan terhadap laba pada bank-bank di Argentina dan Bolivia sementara pada negara Columbia, Chilli dan Peru tidak menunjukkan adanya pengaruh yang signifikan, LDR menunjukkan pengaruh yang signifikan positif terhadap laba pada bank-bank di Bolivia, Columbia dan Peru sementara pada bank di Argentina tidak menunjukkan pengaruh yang signifikan sedangkan $N P L$ menunjukkan pengaruh yang postif terhadap laba pada bank di Columbia namun menunjukkan pengaruh yang negatif terhadap laba pada bank-bank di Argentina dan Peru.

1. Fauzan Adhim (2011) meneliti tentang Analisis Perbandingan Kinerja Keuangan Perbankan Syariah dengan Perbankan Konvensional menunjukkan bahwa hasil Rasio NPL perbankan syariah berbeda signifikan dengan perbankan konvensional. Rasio NPL perbankan syariah lebih rendah dibandingkan perbankan konvensional. Hal ini berarti kualitas NPL perbankan syariah lebih baik dari perbankan konvensional.

2. Rasio rentabilitas yang diwakili oleh variabel rasio ROA (Return on Asset) dan ROE (Return On Equity) antara perbankan syariah dengan perbankan konvensional terdapat perbedaan yang signifikan. Kualitas ROA dan ROE perbankan syariah lebih rendah dibandingkan perbankan konvensional, yang artinya kemampuan perbankan syariah dalam memperoleh laba berdasarkan asset dan modal yang dimiliki masih di bawah perbankan konvensional. 
3. Dilihat dari rasio efisiensi operasional perbankan yang diwakili oleh variabel BOPO (Beban Operasional/Pendapatan Operasional) terdapat perbedaan yang signifikan antara perbankan syariah dengan perbankan konvensional. Dalam hal ini, kinerja Perbankan syariah lebih buruk dibandingkan kinerja perbankan konvensional.

4. Terdapat perbedaan yang signifikan terhadap rasio likuiditas yang diwakili oleh variabel rasio LDR (Loan Deposit Ratio). Perbankan syariah memiliki rasio LDR yang secara signifikan lebih baik kualitasnya dibandingkan dengan perbankan konvensional.

Berdasarkan atas penelitian-penelitian yang telah dilakukan sebelumnya, terdapat kesamaan dengan penelitian yang akan dilakukan yaitu menganalisis tingkat kinerja perusahaan perbankan. Hal yang spesifik pada penelitian ini adalah penilaian kinerja sesuai dengan Peraturan Bank Indonesia Nomor: 9/1/PBI/2007 tentang Sistem Penilaian Tingkat Kesehatan Bank Umum Berdasarkan Prinsip Syariah CAMELS (Capital, Asset, Management, Earnings, Liquidity, Sensitivity to Market Risk) dan obyek penelitian yaitu pada perbankan syariah yaitu Bank Umum Syariah (BUS) dan Unit Usaha Syariah (UUS). Pertimbangan lain mengenai perlunya penelitian ini adalah belum terdapat penelitian yang obyeknya spesifik tentang perbankan syariah.

\section{Metodologi Penelitian}

\section{Objek Penelitian}

Objek penelitian ini adalah bank-bank yang terdiri dari Bank Umum Syariah (BUS) dan Bank Umum yang melakukan kegiatan Unit Usaha Syariah (UUS). Adapun populasi bank yang terdaftar di Bank Indonesia berjumlah 11 Bank Umum Syariah (BUS) dan 29 Unit Usaha Syariah (UUS). Pertimbangan pengambilan sampel adalah dengan mengambil $100 \%$ dari jumlah populasi masing-masing bank devisa dan bank non devisa yang terdaftar di Bank Indonesia.

\section{Sumber dan Jenis Data}

Penelitian ini diperoleh data berupa laporan keuangan bank dari Bank Indonesia melalui situs Bank Indonesia (www.bi.go.id) maupun laporan 
keuangan publikasi dari masing-masing bank. Selain melalui situs juga melakukan studi pustaka untuk memperkuat dan mendukung penelitian ini, yaitu menguraikan teori-teori yang diperlukan dalam pembahasan masalah. Dilakukan dengan cara membaca dan mempelajari buku-buku literatur, jurnal serta tulisan-tulisan yang berkaitan dengan masalah yang diteliti.

Jenis data yang digunakan dalam penelitian ini adalah data sekunder. Sumber data dari Bank Umum Syariah (BUS) dan Unit Usaha Syariah (UUS) yang dijadikan sampel adalah laporan keuangan tahun 2012 yang berupa Neraca, Laporan Laba Rugi, Komitmen dan Kontinjensi, Kualitas Aktiva Produktif dan Informasi Lainnya, Perhitungan Kewajiban Penyediaan Modal Minimum (KPMM) yang diperoleh dari Bank Indonesia.

\section{Populasi dan Sampel}

Populasi adalah seluruh elemen yang dapat digunakan untuk membuat kesimpulan Emory dan Coopeer (2005). Sekaran (1992) mendefinisikan populasi sebagai keseluruhan kelompok baik orang atau sesuatu yang menarik, yang akan diteliti oleh peneliti. Populasi dalam penelitian ini adalah kinerja keuangan perbankan di Indonesia. Dikatakan oleh Emory dan Coopeer (2005) bahwa sampel adalah bagian dari seluruh populasi yang di pilih secara hati-hati untuk mewakili populasi tersebut. Sekaran (1992) menyebutkan bahwa sampel adalah bagian dari populasi. Pengambilan sampel ditujukan untuk kemudahan peneliti dalam meneliti populasinya, dikarenakan faktor kuantitatif obyek penelitian yang semakin sedikit. Hasil yang diperoleh dari penelitian terhadap sampel dari suatu populasi dapat digeneralisasikan pada keseluruhan populasi tersebut. Sampel dalam penelitian ini adalah kinerja keuangan pada perbankan syariah yang terdiri dari 11 Bank Umum Syariah (BUS) dan 29 Unit Usaha Syariah (UUS).

Teknik pengambilan sampel yang digunakan dalam penelitian ini adalah purposive sampling yang merupakan teknik pengambilan sampel dengan pertimbangan atau kriteria tertentu. Sampel yang dipergunakan peneliti adalah 11 Bank Umum Syariah (BUS) yang memiliki kelengkapan laporan keuangan tahun 2012 yang berupa Neraca, Laporan Laba Rugi, Komitmen dan Kontinjensi, Kualitas Aktiva Produktif dan Informasi Lainnya, Perhitungan Kewajiban Penyediaan Modal Minimum (KPMM). Sedangkan 
dari 29 Unit Usaha Syariah (UUS) yang memiliki kelengkapan laporan keuangan unit usaha syariah tahun 2012 yang berupa Neraca, Laporan Laba Rugi, Komitmen dan Kontinjensi, Kualitas Aktiva Produktif dan Informasi Lainnya, Perhitungan Kewajiban Penyediaan Modal Minimum (KPMM) hanya 12 Unit Usaha Syariah (UUS).

\section{Variabel-variabel Operasional}

Variabel merupakan gejala yang bervariasi (Arikunto, 2006), atau segala sesuatu yang berbentuk apa saja yang ditetapkan oleh peneliti untuk dipelajari sehingga diperoleh informasi tentang hal tersebut, kemudian akan ditarik kesimpulannya (Sugiyono, 2003). Variabel yang digunakan dalam penelitian ini terdiri dari:

a. Variabel Independen

Variabel ini sering disebut sebagai variabel bebas, stimulus, input, prediktor, variabel yang mempengaruhi, dan antecedent yaitu variabel yang menjadi sebab timbulnya atau berubahnya variabel dependen. Variabel Independen yang digunakan dalam penelitian ini adalah sebagai berikut:

(1) $\mathrm{X}_{1}=$ Variabel Bank Umum Syariah (BUS)

Pada penelitian ini merupakan penelitian tentang analisis perbedaan kinerja keuangan perbankan syariah pada Bank Umum Syariah (BUS).

(2) $\mathrm{X}_{2}=$ Variabel Unit Usaha Syariah (UUS)

Pada penelitian ini merupakan penelitian tentang analisis perbedaan kinerja keuangan perbankan syariah pada Unit Usaha Syariah (UUS).

b. Variabel Dependen

Variabel dependen sering disebut sebagai variabel respon, output, kriteria, konsekuen, atau variabel terikat, yang merupakan variabel yang dipengaruhi atau yang menjadi akibat karena adanya variabel bebas. Variabel dependen yang digunakan adalah : $\mathrm{Y}=$ Variabel kinerja keuangan perbankan syariah. Perbedaan Bank Umum Syariah dan Unit Usaha Syariah hanya pada status pendirian Bank. Pada Bank Syariah statusnya independen sedangkan Unit Usaha Syariah belum independen dan masih bernaung dari Bank Konvensional atau dengan kata lain UUS merupakan 
salah satu Unit Usaha dari Bank Konvensional. Pada penelitian ini merupakan penelitian tentang analisis perbedaan kinerja keuangan perbankan syariah yang diukur melalui analisa CAMELS (Capital, Asset, Management, Earnings, Liquidity, sensitivity to market risk)antaraBank Umum Syariah (BUS) dan Unit Usaha Syariah (UUS).

Penilaian kinerja keuangan perbankan untuk mencapai tujuan investasinya melalui ukuran tingkat kesehatan bank berdasarkan ketentuan Bank Indonesia mencakup penilaian terhadap faktor-faktor CAMELS yang terdiri dari:

(1) Permodalan (Capital)

Penilaian pendekatan kuantitatif dan kualitatif faktor permodalan dilakukan melalui penilaian terhadap kecukupan pemenuhan Kewajiban Penyediaan Modal Minimum (KPMM) terhadap ketentuan yang berlaku. Pada penelitian ini faktor permodalan dihitung melalui Capital Adequacy Ratio (CAR) dihitung menggunakan rasio antara jumlah modal terhadap aktiva tertimbang menurut resiko (ATMR), Besarnya CAR dirumuskan sebagai berikut (Bank Indonesia, 2007) :

$$
\mathrm{CAR}=\frac{\text { Modal Sendiri }}{\text { ATMR }}
$$

(2) Kualitas Aset (Asset Quality)

Penilaian pendekatan kuantitatif dan kualitatif faktor aset bank dilakukan melalui penilaian terhadap komponen aktiva produktif yang diklasifikasikan dibandingkan dengan total aktiva produktif dan tingkat kecukupan pembentukan penyisihan penghapusan aktiva produktif (PPAP). Besarnya PPAP yang diklasifikasikan dirumuskan sebagai berikut (Bank Indonesia, 2007):

$$
\text { PPAP yang diklasifikasikan }=\frac{\text { Kecukupan PPAP }}{\text { Total Aktiva Produktif }}
$$

(3) Manajemen (Management)

Penelitian Merkusiwati (2007) menggambarkan tingkat kesehatan bank dari aspek manajemen dengan rasio Non Performingt 
Loan (NPL) dan Net Profit Margin (NPM), alasannya karena seluruh kegiatan manajemen suatu bank yang mencakup manajemen umum, manajemen risiko, dan kepatuhan bank pada akhirnya akan mempengaruhi dan bermuara pada perolehan laba. dirumuskan sebagai berikut (Bank Indonesia, 2007) :

Net Profit Margin dihitung dengan membagi Net Income atau laba bersih dengan Operating Income atau laba usaha.

$$
\text { Net Profit Margin }(\mathrm{NPM})=\frac{\text { Net Income }}{\text { Operating Income }}
$$

(4) Profitabilitas (Earnings)

Penilaian pendekatan kuantitatif dan kualitatif faktor profitabilitas bank antara lain dilakukan melalui penilaian terhadap komponenkomponen Return on Assets (ROA), Return on Equity (ROE), Net Interest Margin (NIM) atau Net Operating Margin (NOM), dan Biaya Operasional dibandingkan dengan Pendapatan Operasional (BOPO). Besarnya ROA dirumuskan sebagai berikut (Bank Indonesia, 2007):

$$
\text { Return on Assets }(\mathrm{ROA})=\frac{\text { Laba Bersih }}{\text { Total Aktiva }}
$$

(5) Likuiditas (Liquidity)

Penilaian pendekatan kuantitatif dan kualitatif faktor likuiditas bank dilakukan melalui penilaian terhadap komponen Loan to Deposit Ratio (LDR). LDR menunjukkan seberapa jauh kemampuan bank dalam membayar kembali penarikan dana yang dilakukan deposan dengan mengandalkan kredit yang diberikan sebagai sumber likuiditasnya Besarnya LDR dirumuskan sebagai berikut (Bank Indonesia, 2007):

$$
\mathrm{LDR}=\frac{\text { Jumlah Kredit yang Diberikan }}{\text { Total Dana Pihak Ketiga }}
$$


(6) Sensitivitas terhadap Risiko Pasar (Sensitivity to Market Risk) Penilaian rasio sensitivitas terhadap risiko pasar didasarkan pada Interest Rate Risk Ratio (IRRR) yang proksi terhadap risiko pasar. IRRR menunjukkan kemampuan bank dalam mengcover biaya bunga yang harus dikeluarkan dengan pendapatan bunga yang dihasilkan. Besarnya IRRR dirumuskan sebagai berikut (Bank Indonesia, 2007):

$$
\operatorname{IRRR}=\frac{\text { Biaya Bunga }}{\text { Pendapatan Bunga }}
$$

\section{Metode Analisis}

Metode analisis yang digunakan dalam menguji penelitian ini berupa uji perbedaan dua mean (test of differences). Uji perbedaan dua mean (test of differences) dalam analisis bivariate berupa perbedaan dua kategori/ kelompok data (Jogianto, 2005). Pada penelitian ini dua kelompok sampel tidak berpasangan yaitu kelompok Bank Umum Syariah (BUS) dan Bank Unit Usaha Syariah (UUS). Independent samples t test (uji t untuk rata-rata dua sampel independen) sebenarnya adalah uji t untuk mengamati perbedaan rata-rata sampel yang tidak saling berhubungan. Uji ini khusus digunakan untuk menentukan apakah terdapat perbedaan yang signifikan antara ratarata dari setiap kelompok yang diamati, yaitu untuk mengetahui apakah terdapat perbedaan kinerja antara kelompok Bank Umum Syariah (BUS) dan Bank Unit Usaha Syariah (UUS) dilakukan uji statistik dengan sample t-test beda rata-rata atas kinerja 11 Bank Umum Syariah (BUS) dan 12 Unit Usaha Syariah (UUS).

Rumus yang digunakan :

$$
\begin{gathered}
t=\frac{\bar{D}-\mu_{D}}{\frac{S_{D}}{\sqrt{n}}} \\
\bar{D}=\frac{\sum D}{n}
\end{gathered}
$$




$$
\begin{aligned}
& \bar{D}=X_{1}-X_{2} \\
& S_{D}=\sqrt{\frac{\sum D^{2}-\frac{\left(\sum D\right)^{2}}{n}}{n-1}}
\end{aligned}
$$

Keterangan:

$\mu_{\mathrm{D}}=$ Nilai rata-rata populasi sampel

$\mathrm{t}=\mathrm{Uji}$ perbedaan dua mean (test of differences)

$\mathrm{S}_{\mathrm{D}}=$ Perbedaan deviasi standar dua sampel

$\mathrm{D}=$ Jumlah nilai kelompok (Define Group)

$=$ Perbedaan nilai rata-rata dua sampel

$\mathrm{n}=$ Jumlah sampel yang diteliti

$\mathrm{X}_{1}=$ Nilai rata-rata sampel 1 (kelompok Bank Umum Syariah/BUS)

$\mathrm{X}_{2}=$ Nilai rata-rata sampel 2 (kelompok Unit Usaha Syariah /UUS)

\section{Hipotesis Penelitian}

Hipotesis yang akan diuji untuk mencapai tujuan penelitian adalah sebagai berikut:

H1 : Ada perbedaan yang signifikan antara kinerja perbankan syariah (Bank Umum Syariah) dengan perbankan konvensional yang mempunyai Unit Usaha Syariah (UUS), jika dilihat dari rasio permodalan.

H2 : Ada perbedaan yang signifikan antara kinerja perbankan syariah (Bank Umum Syariah) dengan perbankan konvensional yang mempunyai Unit Usaha Syariah (UUS), jika dilihat dari rasio kualitas aktiva produktif.

H3 : Ada perbedaan yang signifikan antara kinerja perbankan syariah (Bank Umum Syariah) dengan perbankan konvensional yang mempunyai Unit Usaha Syariah (UUS), jika dilihat dari rasio manajemen.

H4 : Ada perbedaan yang signifikan antara kinerja perbankan syariah (Bank Umum Syariah) dengan perbankan konvensional yang mempunyai Unit Usaha Syariah (UUS), jika dilihat dari rasio rentabilitas. 
H5 : Ada perbedaan yang signifikan antara kinerja perbankan syariah(Bank Umum Syariah) dengan perbankan konvensional yang mempunyai Unit Usaha Syariah (UUS), jika dilihat dari rasio likuiditas.

H6 : Ada perbedaan yang signifikan antara kinerja perbankan syariah (Bank Umum Syariah) dengan perbankan konvensional yang mempunyai Unit Usaha Syariah (UUS), jika dilihat dari rasio sensitivitas terhadap resiko pasar.

H7 : Ada perbedaan yang signifikan antara kinerja perbankan syariah (Bank Umum Syariah dengan Unit Usaha Syariah) secara keseluruhan.

\section{Kinerja Keuangan Perbankan BUS dan UUS}

Kinerja keuangan perbankan syariah pada Bank Umum Syariah (BUS) dan Unit Usaha Syariah (UUS) untuk masing-masing rasio keuangan secara statistik memperlihatkan hasil sebagai berikut:

a. Tidak ada perbedaan yang signifikan antara kinerja keuangan perbankan syariah (Bank Umum Syariah) dengan perbankan konvensional yang mempunyai Unit Usaha Syariah (UUS) jika dilihat dari rasio permodalan (CAR) dan rasio kualitas aktiva produktif (PPAP). Hasil analisis tersebut memperlihatkan bahwa kinerja keuangan perbankan syariah jika dilihat dari rasio permodalan (CAR) dan rasio kualitas aktiva produktif (PPAP) antara (Bank Umum Syariah) dengan perbankan konvensional yang mempunyai Unit Usaha Syariah (UUS) adalah sama. Artinya kemampuan Bank Umum Syariah dan perbankan konvensional yang mempunyai Unit Usaha Syariah (UUS) dalam menyediakan rasio kecukupan modal dan (CAR) dan rasio kualitas aktiva produktif (PPAP) adalah sama. Penelitian ini selaras dengan penelitian yang telah dilakukan oleh Fauzan Adhim (2011) yang meneliti tentang Analisis Perbandingan Kinerja Keuangan Perbankan Syariah dengan Perbankan Konvensional menunjukkan bahwa hasil uji statistic independent sample $t$-test menunjukkan rasio CAR perbankan syariah tidak berbeda secara signifikan dengan perbankan konvensional.

b. Ada perbedaan yang signifikan antara kinerja keuangan perbankan syariah (Bank Umum Syariah) dengan perbankan konvensional yang mempunyai Unit Usaha Syariah (UUS) jika dilihat dari rasio manajemen 
(NPM), rasio profitabilitas (ROA), rasio likuiditas (LDR), dan rasio sensitifitas terhadap reaksi pasar - Interest Rate Risk Ratio (IRRR). Hasil analisis tersebut memperlihatkan bahwa kinerja keuangan perbankan syariah jika dilihat dari rasio manajemen (NPM), rasio profitabilitas (ROA), rasio likuiditas (LDR), dan rasio sensitifitas terhadap reaksi pasar - Interest Rate Risk Ratio (IRRR) antara (Bank Umum Syariah) dengan perbankan konvensional yang mempunyai Unit Usaha Syariah (UUS) adalah berbeda. Artinya kemampuan Bank Umum Syariah dan perbankan konvensional yang mempunyai Unit Usaha Syariah (UUS) dalam menyediakan rasio manajemen (NPM), rasio profitabilitas (ROA), rasio likuiditas (LDR), dan rasio sensitifitas terhadap reaksi pasar - Interest Rate Risk Ratio (IRRR) adalah berbeda. Kinerja keuangan perbankan syariah dalam menyediakan rasio manajemen (NPM), rasio likuiditas (LDR), dan rasio sensitifitas terhadap reaksi pasar - Interest Rate Risk Ratio (IRRR) pada Bank Umum Syariah (BUS) lebih besar atau lebih tinggi dari pada perbankan konvensional yang mempunyai Unit Usaha Syariah (UUS). Ini tidak berlaku pada kinerja keuangan rasio profitabilitas (ROA) pada perbankan konvensional yang mempunyai Unit Usaha Syariah (UUS) lebih besar atau lebih tinggi dari pada Bank Umum Syariah (BUS).

\section{Kinerja Keuangan BUS dan UUS untuk Rasio Keuangan Keseluruhan}

Ada perbedaan yang signifikan antara kinerja keuangan perbankan syariah (Bank Umum Syariah) dengan perbankan konvensional yang mempunyai Unit Usaha Syariah (UUS) jika dilihat dari rasio kinerja keuangan perbankan syariah secara keseluruhan. Hasil analisis tersebut memperlihatkan bahwa kinerja keuangan perbankan syariah secara keseluruhan antara (Bank Umum Syariah) dengan perbankan konvensional yang mempunyai Unit Usaha Syariah (UUS) adalah berbeda.

Penelitian ini selaras dengan penelitian yang telah dilakukan oleh Fauzan Adhim (2011) yang meneliti tentang Analisis Perbandingan Kinerja Keuangan Perbankan Syariah dengan Perbankan Konvensional. Hasil penelitian menunjukkan bahwa hasil uji statistic independent sample t-test 
menunjukkan bahwa kinerja bank secara keseluruhan yang diwakili oleh variabel "Kinerja" terdapat perbedaan yang signifikan antara kinerja perbankan syariah dibandingkan dengan perbankan konvensional.

Secara keseluruhan hasil rekapitulasi dari analisis statistik Uji Beda $t$-Test dapat terlihat pada tabel berikut ini:

Tabel 2.

Hasil Analisis Statistik Deskriptif Kinerja Perbankan BUS \& UUS

\begin{tabular}{|c|c|c|c|c|c|c|}
\hline \multirow{2}{*}{ Rasio } & \multicolumn{2}{|c|}{$\mathrm{N}$ (Amatan) } & \multicolumn{2}{|c|}{ Rata-Rata } & \multicolumn{2}{|c|}{ Selisih } \\
\hline & BUS & UUS & BUS & UUS & BUS & UUS \\
\hline $\begin{array}{l}\text { 1. Rasio Permodalan- } \\
\text { CAR }\end{array}$ & 11 & 12 & $22,98 \%$ & $17,87 \%$ & $5,11 \%$ & - \\
\hline $\begin{array}{l}\text { 2. Rasio Kualitas } \\
\text { Aktiva Produktif- } \\
\text { PPAP }\end{array}$ & 11 & 12 & $1,30 \%$ & $2,11 \%$ & - & $0,81 \%$ \\
\hline $\begin{array}{l}\text { 3. Rasio Manajemen - } \\
\text { NPM }\end{array}$ & 11 & 12 & $89,93 \%$ & $0,25 \%$ & $89,68 \%$ & - \\
\hline $\begin{array}{l}\text { 4. Rasio Profitabilitas - } \\
\mathrm{RO} \Lambda\end{array}$ & 11 & 12 & $1,34 \%$ & $2,7 \%$ & - & $1,36 \%$ \\
\hline $\begin{array}{l}\text { 5. Rasio Likuiditas - } \\
\text { LDR }\end{array}$ & 11 & 12 & $104,93 \%$ & $83,01 \%$ & $21,93 \%$ & \\
\hline $\begin{array}{l}\text { a. RasioSensitivitas } \\
\text { lerhadap Risiko } \\
\text { Pasar } \\
\end{array}$ & 11 & 12 & $585,92 \%$ & $0,85 \%$ & $585,07 \%$ & \\
\hline $\begin{array}{l}\text { b. Rasio Kinerja } \\
\text { Keuangan } \\
\text { Perbankan Syariah }\end{array}$ & 11 & 12 & $136,48 \%$ & $17,80 \%$ & $118,69 \%$ & \\
\hline
\end{tabular}

Sumber: hasil olah data, 2013

Tabel 3. Uji Beda-F Test

\begin{tabular}{|l|c|c|c|c|}
\hline Keterangan & $\begin{array}{c}\text { Hasil F- } \\
\text { Test }\end{array}$ & $\begin{array}{c}\text { Probabilitas } \\
\mathbf{\alpha} 5 \%\end{array}$ & $\begin{array}{c}\text { Equal } \\
\text { Variance } \\
\text { Assumed }\end{array}$ & $\begin{array}{c}\text { Equal } \\
\text { Variance Not } \\
\text { Assumed }\end{array}$ \\
\hline $\begin{array}{l}\text { 1. Rasio Permodalan- } \\
\text { CAR }\end{array}$ & 8,483 & 0,008 & - & $\sqrt{ }$ \\
\hline $\begin{array}{l}\text { 2. Rasio Kualitas } \\
\Lambda \text { ktiva Produktif- } \\
\text { PPAP }\end{array}$ & 6,644 & 0,018 & - & $\sqrt{ }$ \\
\hline
\end{tabular}




\begin{tabular}{|l|c|c|c|c|}
\hline Keterangan & $\begin{array}{c}\text { Hasil F- } \\
\text { Test }\end{array}$ & $\begin{array}{c}\text { Probabilitas } \\
\boldsymbol{\alpha} 5 \%\end{array}$ & $\begin{array}{c}\text { Equal } \\
\text { Variance } \\
\text { Assumed }\end{array}$ & $\begin{array}{c}\text { Equal } \\
\text { Variance Not } \\
\text { Assumed }\end{array}$ \\
\hline $\begin{array}{l}\text { 3. Rasio Manajemen } \\
\text { NPM }\end{array}$ & 21,425 & 0,000 & - & $\sqrt{ }$ \\
\hline $\begin{array}{l}\text { 4. Rasio Profitabilitas } \\
\text { - ROA }\end{array}$ & 0,866 & 0,363 & $\sqrt{ }$ & - \\
\hline $\begin{array}{l}\text { 5. Rasio Likuiditas } \\
\text { LDR }\end{array}$ & 2,531 & 0,127 & $\sqrt{ }$ & $\sqrt{ }$ \\
\hline $\begin{array}{l}\text { 6. RasioSensitivitas } \\
\text { terhadap Risiko } \\
\text { Pasar }\end{array}$ & 23,230 & 0,000 & - & $\sqrt{ }$ \\
\hline $\begin{array}{l}\text { 7. Rasio Kinerja } \\
\text { Keuangan } \\
\text { Pcrbankan Syariah }\end{array}$ & $27,58 \%$ & 0,000 & - & \\
\hline
\end{tabular}

Sumber: hasil olah data, 2013

Tabel 4. Rekapitulasi Hasil Uji Beda t-Test

\begin{tabular}{|l|c|c|c|c|c|}
\hline Keterangan & $\begin{array}{c}\text { Hasil } \\
\text { t-Test }\end{array}$ & $\begin{array}{c}\text { Probabilitasa } \\
(5 \% / 2 \text { sisi } \\
2,5 \%)\end{array}$ & $\begin{array}{c}\text { Ho } \\
\text { ditolak }\end{array}$ & $\begin{array}{c}\text { Ho tidak } \\
\text { dapatditolak }\end{array}$ & $\begin{array}{c}\text { Rata- } \\
\text { Rata } \\
\text { (mean) } \\
\text { Rasio }\end{array}$ \\
\hline $\begin{array}{l}\text { 1. Rasio Permodalan- } \\
\text { CAR }\end{array}$ & $1,076 \%$ & 0,1525 & - & $\sqrt{ }$ & Sama \\
\hline $\begin{array}{l}\text { 2. Rasio Kualitas } \\
\text { Aktiva Produktif- } \\
\text { PP } \Lambda \text { P }\end{array}$ & $1,380 \%$ & 0,0965 & - & $\sqrt{ }$ & Sama \\
\hline $\begin{array}{l}\text { 3. Rasio Manajemen } \\
- \text { NPM }\end{array}$ & $13,59 \%$ & 0,000 & $\sqrt{ }$ & - & Berbeda \\
\hline $\begin{array}{l}\text { 4. Rasio rofitabilitas } \\
\text { - ROA }\end{array}$ & $3,643 \%$ & 0,001 & $\sqrt{ }$ & - & Berbeda \\
\hline $\begin{array}{l}\text { 5. Rasio Likuiditas - } \\
\text { I.DR }\end{array}$ & $4,610 \%$ & 0,000 & $\sqrt{ }$ & - & Berbeda \\
\hline $\begin{array}{l}\text { 6. RasioSensilivilas } \\
\text { terhadap Risiko } \\
\text { Pasar }\end{array}$ & $4,448 \%$ & 0,000 & $\sqrt{ }$ & - & Berbeda \\
\hline $\begin{array}{l}\text { 7. Rasio Kincrja } \\
\text { Keuangan } \\
\text { Perbankan Syariah }\end{array}$ & $3,64 \%$ & 0,000 & $\sqrt{ }$ & - & \\
\hline
\end{tabular}




\section{Penutup}

Berdasarkan hasil analisa data dan hasil penelitian pada bab sebelumnya maka dapat diperoleh simpulan sebagai berikut:

1. Berdasarkan analisis uji beda rata-rata $t$-Test memperlihatkan tidak ada perbedaan yang signifikan antara kinerja keuangan perbankan syariah (Bank Umum Syariah) dengan perbankan konvensional yang mempunyai Unit Usaha Syariah (UUS) jika dilihat dari rasio permodalan (CAR) dan rasio kualitas aktiva produktif (PPAP).

2. Ada perbedaan yang signifikan antara kinerja keuangan perbankan syariah (Bank Umum Syariah) dengan perbankan konvensional yang mempunyai Unit Usaha Syariah (UUS) jika dilihat dari rasio manajemen (NPM), rasio profitabilitas (ROA), rasio likuiditas (LDR), dan rasio sensitifitas terhadap reaksi pasar - Interest Rate Risk Ratio (IRRR).

3. Ada perbedaan yang signifikan antara kinerja keuangan perbankan syariah (Bank Umum Syariah) dengan perbankan konvensional yang mempunyai Unit Usaha Syariah (UUS) jika dilihat dari rasio kinerja keuangan perbankan syariah secara keseluruhan.

Penelitian ini memiliki keterbatasan dalam kelengkapan laporan keuangan Unit Usaha Syariah tahun 2012 yaitu berupa tidak dipublikasikan laporan keuangan yang terkait Unit Usaha Syariah (UUS), karena hanya 12 bank konvensional yang mempunyai Unit Usaha Syariah yang mempublikasikan laporannya. 17 bank konvensional yang mempunyai Unit Usaha Syariah yang tidak mempublikasikan laporan keuangan Unit Usaha Syariah, bank tersebut hanya mempublikasikan laporan keuangan bank konvensional yaitu berupa: Neraca, Laporan Laba Rugi, Komitmen dan Kontinjensi, Kualitas Aktiva Produktif dan Informasi Lainnya, Perhitungan Kewajiban Penyediaan Modal Minimum (KPMM) hanya 12.

Kontribusi yang diberikan dari hasil penelitian ini diharapkan dapat dijadikan sebagai bahan informasi tambahan bagi para peneliti di tahuntahun yang akan datang. 


\section{Daftar Pustaka}

Apostolik, Richard., Donohue C., Went, Peter. Foundation of Banking Risk: An overview of Banking, Banking Risks, and Risk-based Banking Regulation, USA: John Wiley \& Sons, Inc.,2009.

Arifin, Zainul. Dasar-dasar Manajemen Bank Syariah. Jakarta: Alvabet, 2002.

Aryati, Titik dan Hekinus Manao. "Rasio Keuangan sebagai Prediktor Bank Bermasalah di Indonesia", Jurnal Riset Akuntansi Indonesia, 5( 2), Mei 2002, hal. 137-147.

Bahtiar, Usman. "Analisis Rasio Keuangan Dalam Memprediksi Perubahan Laba Pada Bank-Bank di Indonesia",Media Riset Bisnis dan Manajemen, 3 (1), April 2003, hal.59-74.

Bank Indonesia., Direktori Perbankan Indonesia, Jakarta, 2013.

Brock, P,L and L Rojas-Suarez, "Understanding The Behavior of Bank Spreads in Latin America",Journal of Development Economics 63, 2000, pp 113-134.

Cooper R.D and Emory W.C., Bussiness Research Methods (5 ${ }^{\text {th }}$ ed.), London: Richard D. Irwin, Inc., 2005.

Dusuki, Asyraf Wajdi and Nurdianawati Irwani Abdullah. 2007. Why Do Customers patrionise Islamic Banks?. International Journal of Bank Marketing. Vol 25.No. 3, 2007.

Erawati, Dewi., Perbedaan Kinerja Keuangan Perbankan menggunakan Metode EAGLES antara Bank Swasta Nasional dan Bank Pemerintah Periode 2007-2009, 2010.

Fauzan Adhim, "Analisis Perbandingan Kinerja Keuangan Perbankan Syariah dengan Perbankan Konvensional”,Jurnal Ekonomi Islam. Al-Infaq. Vol 2 N0. 2, 2011

Fira, Bayuningtyas. "Analisa Perbedaan Kinerja Keuangan Tahun Bank antara Bank Swasta Nasional dengan Bank Pemerintah 2010". (http:// student research.umm.ac.id.html, diakses 7 Maret 2013).

Indira, Januarti. "Variabel Proksi CAMEL dan Karakteristik Bank Lainnya Untuk Memprediksi Kebangkrutan Bank di Indonesia", Jurnal BisnisStrategi, 10, Desember 2002, hal. 1-26.

Jogiyanto, Hartono. Metodologi Penelitian Bisnis-Salah Kaprah dan Pengalaman, Edisi Kelima Cetakan Pertama, Yogyakarta: BPFE, 2013.

Merkusiwati, Ni Ketut Lely Aryani."Evaluasi Pengaruh CAMEL Terhadap Kinerja Perusahaan”, Buletin Studi Ekonomi, 2007, Vol 12, No. 1. 
Nurmadi H. Sumarta, Yogiyanto. "Evaluasi Kinerja Perusahaan Perbankan yang Terdaftar di Bursa Efek Indonesia dan Thailand", Buletin Ekonomi Moneter dan Perbankan, September 2000. h.15.

Sekaran, U. Research Methods for Bussiness: A Skill - Building Approach (2th ed). New York: John Wiley \& Sons, Inc, 1992.

Sugiono. Metode Penelitian Bisnis. Cetakan Pertama. Bandung: Alfabeta, 2004. 